\title{
GAMBARAN HEMATOKRIT DARAH IKAN LELE SANGKURIANG (Clarias Gariepinus) YANG DIBERI PAKAN SERBUK DAUN MAJAPAHIT (Cresentia cujete L.) DAN DIINFEKSI DENGAN BAKTERI AEROMONAS HYDROPHILA
}

\author{
Sri Rahmaningsih", Muhammad Zenuddin, dan Achmad Sudianto \\ Prodi Ilmu Perikanan Fakultas Perikanan dan Kelautan Universitas PGRI Ronggolawe \\ Jl Manunggal No 61 Tuban , 0356-322233 Faks, 0356-331578 \\ E-mail : rahmaningsihsri@yahoo.co.id
}

(Diterima: 29 November 2018; Diterima setelah perbaikan: 14 Desember 2018; Disetujui: 18 Desember 2018)

\begin{abstract}
ABSTRAK
Pengukuran hematologis darah ikan dapat dijadikan sebagai indikator kesehatan ikan. Salah satu penyakit yang sering menyerang pada budidaya ikan lele sangkuriang (Clarias Gariepenus) adalah penyakit bercak merah atau penyakit MAS (Motile Aeromonas Septicemia) yang dapat menyebakan tingkatmortalitas tinggi. Penyakit ini disebabkan oleh bakteri Aeromonas hydrophila, yang termasuk bakteri gram negatif. Salah satu alternatif yang digunakan untuk mengatasi permasalahan serangan penyakit adalah dengan menggunakan bahan alami yang aman dan ramah lingkungan. Tumbuhan dapat dijadikan sebagai antibakteri dan imunostimulan, misalnya tumbuhan majapahit (Crescentia cujete L.) yang mempunyai kandungan kimia pada daun, batang dan daun. Kandungan bahan aktif tersebut adalah flavonoid, tanin, polifenol dan saponin. Penggunaan imunostimulan dalam budidaya perikanan dilaporkan dapat meningkatkan ketahanan tubuh terhadap resistensi patogen selama masa periode stress seperti saat griding, reproduksi, pengangkutan dan vaksinasi. Kadar hematokrit adalah salah satu parameter hematologis yang digunakan untuk mengetahui dampak infeksi dari A. Hydrophila. Penelitian ini bertujuan untuk mengetahui pengaruh serbuk daun majapahit (Crescentia cujete L.) sebagai bahan imunostimulan pada benih ikan lele sangkuriang (Clarias gariepenus) yang terinfeksi oleh bakteri Aeromonas hydrophyla terhadap gambaran hematokritnya. Metode yang dipakai adalah menggunakan Rancangan Acak Lengkap dengan 4 perlakuan dan 3 x ulangan serta analisa data menggunakan ANOVA. Kesimpulan dari hasil penelitian ini menunjukkan bahwa dosis terbaik yang menunjukkan nilai hematokrit tertinggi adalah pada perlakuan A dengan dosis 7.5\%.
\end{abstract}

\section{KATA KUNCI: Hematokrit; Aeromonas hydrophila; lele sangkuriang; Crescentia cujete}

\begin{abstract}
Hematological measurements of fish blood can be used as indicators of fish health. One of the diseases that often attacks the sangkuriang catfish culture (Clarias Gariepenus) is a red spot disease or called MAS (Motile Aeromonas Septicemia) that can cause a high mortality rate. This disease was caused by the bacterium Aeromonas hydrophila, which includes gram negative bacteria. One alternative that is used to overcome the problem of disease attacks is to use natural materials that are safe and environmentally friendly. Plants can be used as antibacterial and immunostimulant, for example majapahit plants (Crescentia cujete L.) which have a chemical content in leaves, stems and leaves. These active ingredients are flavonoids, tannins, polyphenols and saponins. The use of immunostimulants in aquaculture was reported to increase the body's resistance to pathogenic resistance during periods of stress such as griding, reproduction, transportation and vaccination. Hematocrit levels are one of the haematological parameters used to determine the effect of infection from A. Hydrophila. This study aims to determine the effect of majapahit leaf powder (Crescentia cujete L.) as an immunostimulant on sangkuriang catfish seeds (Clarias gariepenus)
\end{abstract}

\footnotetext{
\# Korespondensi: Prodi Ilmu Perikanan Fakultas Perikanan dan

Kelautan Universitas PGRI Ronggolawe

E-mail: rahmaningsihsri@yahoo.co.id
} 
which is infected by the bacterium Aeromonas hydrophyla against the hematocrit picture. The method used is using a completely randomized design with 4 treatments and $3 \mathrm{x}$ replications and data analysis using ANOVA. Conclusions from the results of this study indicate that the best dose that shows the highest hematocrit value is in treatment A with a dose of 7.5\%

\section{KEYWORDS: Hematokrit; Aeromonas hydrophila; sangkuriang catfish Crescentia cujete}

\section{PENDAHULUAN}

Penyakit yang sering berkembang pada kegiatan akuakultur, salah satunya dalam budidaya ikan lele (Clarias $s p$ ) adalah penyakit bercak merah yang disebabkan oleh bakteri Aeromonas hydrophila.Bakteri Aeromonas hydrophila merupakan bakteri gram negatif, yang bersifat pathogen pada ikan. Bakteri $A$. hydrophila merupakan bakteri patogen oportunistik penyebab penyakit MAS (Motile Aeromonas Septicemia)yang banyak menyerangpada budidaya ikan air tawar di Indonesia di antaranya; ikan lele (Clarias sp), ikan mas (Cyprinus carpio), patin (Pangasius sp.), betutu (Osphronemous marmorata) dan gurame (Osphronemous. gouramy).

Budidaya ikan Lele sangkuriang (Clarias gariepenus) cukup berkembang di Kabupaten Tuban karena lebih menguntungkan dan mudah dalam pengelolaannya serta dalam pemeliharaannya. Masalah yang dihadapi olehpetani ikandiantaranya adalah tingkatmortalitas tinggi yang disebaban oleh penyakit bakterial khususnya penyakit MAS yang disebabkan oleh bakteri A. hydrophila.Penggunaan imunostimulan dalam budidaya perikanan dilaporkan dapat meningkatkan ketahanan tubuh terhadap resistensi patogen selama masa periode stress seperti saat griding, reproduksi, pengangkutan dan vaksinasi (Bricknell dan Dalmo, 2005). Penggunaan imunostimulan sebagai pakan suplemen dapat meningkatkan pertahanan alami sehingga resisten terhadap patogen. Imunostimulan tidak memperlihatkan efek samping yang negatif sebagaimana antibiotik terhadap lingkungan (Kumari dan Sahoo 2006 dalam Jasmanindar, 2009). Penggunaan imunostimulan berbahan tumbuhan ataupun rumput laut telah banyak dilakukan penelitian terhadap respon imun udang vannamei salah satunya yang dilakukan oleh Ridho dan Pramesti, (2009) menyatakan bahwa pemberian ekstrak rumput laut Sargassum sp., Dictyota sp. dan Padina sp., mampu meningkatkan aktivitas fagositosis udang Litopenaeus vannamei terutama pada hari ke-8, hal ini disebabkan dalam ketiga jenis rumput laut tersebut mengandung senyawa polisakarida alginat. Menurut Cheng et al. (2005), sodium alginat dapat meningkatkan aktifitas fagositosis udang. Disamping itu, Subagiyo (2009) menyatakan bahwa ekstrak rumput laut jenis Halimeda sp. dapat meningkatkan aktifitas fagositosis pada hari ke-12 sebesar $76,78 \%$.
Berdasarkan penelitian terdahulu secara in vitro maupun insilico penggunaan tanaman majapahit (Crescentia cujete L) baik pada bagian batang, daun dan buah terbukti dapat menghambat pertumbuhan bakteri Vibrio harveyi (Rahmaningsih dan Jumiati (2016), ikan lele (Purwanti, 2016) ikan nila (Lutfi, 2017) serta berpengaruh terhadap sistem imun udang vannamei (Rahmaningsih dan Andriani, 2016). Berdasarkan uji fitokimia pada penelitian terdahulu menurut Rahmaningsih dan Jumiati, (2016) kandungan bahan aktif yang terkandung pada daun dan batang adalah tanin, saponin, triterpenoid dan steroid,sedangkan bahan aktif yang terkandung pada buah majapahit adalah flavonoid, saponin dan triterpenoid (Rahmaningsih, 2017).Pengunaan buah dan daun maja sebagai anti bakteri pernah dilakukan penelitian pada bakteri Staphylococus aureus, Aeromonas salmonicidal, V. harveyi dan V. alginolyticus secara in vitro. Penelitian secara in vivo juga telah dilakukan pada ikan lele yang terinfeksi bakteri Aeromonas hydropila(Purwanti, 2016) dan pada ikan nila (Lutfi, 2017), Vibrio harveyi pada udang vannamei (Rahmaningsih dan Andriani, 2016). Penelitian ini bertujuan untuk mengetahui pengaruh serbuk daun majapahit (Crescentia cujete L.) sebagai bahan imunostimulan pada benih ikan lele sangkuriang (Clarias gariepenus) yang terinfeksi oleh bakteri Aeromonas hydrophyla terhadap parameter hematokritnya.

\section{BAHAN DAN METODE}

Penelitian ini dilaksanakan di Laboratorium Ilmu Perikanan Fakultas Perikanan dan Kelautan UNIROW pada bulan Maret sampai Mei 2018. Alat yang digunakan antara lain: Akuarium, gelas ukur, tabung reaksi, mikropipet, mikroskop, lemari pendingin, hemositometer, dan peralatan kualitas air untuk mengukur DO, suhu, $\mathrm{pH}$, dan amonia.Bahan yang digunakan: ikan lele sangkuriang (Clarias gariepenus)dengan berat rata-rata $10 \mathrm{gram} / \mathrm{ekor}$ sebanyak 100 ekor, larutan Turk, heyem, kapas, tissue, aquadest, alkohol $70 \%$, darah ikan, es, antikoagulan (Na-Sitrat 3,8\%), metil alkohol, dan Giemsa.

Ikan lele dipelihara dalam aquarium berkapasitas 20 liter air selama 28 hari dan diberi pakan pelet komersil yang dicampur dengan serbuk daun majapahit 
dengan menggunakan perekat progol. Pakan diberikan sebanyak $5 \%$ dari berat badan ikan dan diberikan dua kali sehari yaitu pagi pukul 08.00 pagi dan sore pukul 16.00 selama satu bulan.Perlakuan dalam penelitian ini sebanyak 4 perlakuan dengan masing-masing 3 kali ulangan, yaitu ; Perlakuan A: pakan komersil + 7.5\% serbuk daun majapahit, perlakuan B: pakan komersil $+10 \%$ serbuk daun majapahit dan Perlakuan $\mathrm{C}$ :pakan komersil $+12,5 \%$ serbuk daun majapahit dan perlakuan D: kontrol (pakan pelet komersial).

Penghitungan kadar hematokrit dilakukan untuk melihat perubahan hematokrit yang terjadi setelah ikan diberi pakan dengan campuran serbuk daun majapahit dan setelah diinfeksi dengan bakteri $A$. hydrophila. Penginfeksian dilakukan dengan perendaman, setelah muncul gejala klinis penyakit MAS yaitu setelah hari ke-3 kemudian dilakukan pengukuran nilai hematokrit.Pengukuran menggunakan tabung mikrohematokrit berupa pipa kapiler yang berlapis heparin. Sampel darah dihisap dengan menggunakan pipa kapiler, sampai pada $3 / 4$ bagian kapiler, kemudian ditutup dengan bahan penutup (lilin). Pipa kapiler yang berisi darah kemudian disentrifuse dengan kecepatan $1500 \mathrm{rpm}$ selama 5 menit. Pembacaan dilakukan dengan membandingkan bagian darah yang mengendap dengan seluruh bagian darah yang ada di dalam tabung mikrohematokrit, menggunakan mikrohematokrit skala dan hasilnya dinyatakan dalam persen (\%) (Angka et al. 1985) dalamDopongtonung (2008).

\section{HASIL DAN PEMBAHASAN}

Hematokrit digunakan untuk mengukur perbandingan antara eritrosit dengan plasma, sehingga hematokrit memberikan rasio total eritrosit dengan total volume darah dalam tubuh Hasil pengukuran hematokrit selama penelitian di tampilkan pada tabel 1 dibawah ini :

Tabel 1. Kadar hematokrit pada ikan lele sangkuriang selama penelitian

\begin{tabular}{|c|c|c|c|}
\hline \multirow{2}{*}{ Perlakuan } & \multicolumn{3}{|c|}{ Kadar hematokrit (\%) } \\
\cline { 2 - 4 } & Awal penelitian & $\begin{array}{c}\text { Setelah pemeliharaan } \\
\text { selama 30 hari }\end{array}$ & $\begin{array}{c}\text { Setelah infeksi hari } \\
\text { ke-3 }\end{array}$ \\
\hline A & $35,17 \pm 0,69$ & $15,12 \pm 0,25$ & $25,42 \pm 0,41$ \\
\hline B & $17,99 \pm 0,13$ & $25,94 \pm 0,17$ & $25,13 \pm 0,14$ \\
\hline C & $22,40 \pm 0,44$ & $22,47 \pm 0,50$ & $24,09 \pm 0,03$ \\
\hline K & $18,41 \pm 0,36$ & $39,04 \pm 0,12$ & $32,04 \pm 018$ \\
\hline
\end{tabular}

Tabel 2. Hasil analisa sidik ragam perlakuan

\begin{tabular}{lrrrrcc}
\hline \multicolumn{1}{c}{ sumber } & & & & & $\mathrm{f}$ tabel & $\mathrm{f}$ tabel \\
\multicolumn{1}{c}{ ragam } & DB & jumlah kuadrat & kuadrat tengah & $\mathrm{f}$ hitung & \multicolumn{1}{c}{$1 \%$} & \multicolumn{1}{c}{$5 \%$} \\
\hline perlakuan & 2 & 203,20 & 101,60 & 752,60 & 18,00 & 5,14 \\
Galat & 6 & 0,81 & 0,14 & & & \\
Total & 8 & 204,01 & 101,74 & & & \\
\hline
\end{tabular}

Dari Tabel 1 diatas menunjukkan bahwa semua perlakuan memberikan pengaruh yang hampir sama yaitu terjadi peningkatan prosentase hematokrit pasca ikan diinfeksi dengan bakteri $A$. hydrophila, kecuali perlakuan $B$ yang justru menurun meskipun tidak banyak. Dari data yang diperoleh selanjutnya dilakukan analisa ANOVA, hasil analisa menunjukkan bahwa perlakuan memberikan pengaruh sangat nyata.

Dari Tabel 2 diatas dapat diketahui bahwa F hitung lebih besar dari $\mathrm{F}$ tabel 1\%dan 5\%,sehingga perlakuan memberikan pengaruh yang sangat nyata pada penelitian. Fujaya (2004) menyatakan bahwa terdapat korelasi yang kuat antara hematokrit dan jumlah hemoglobin darah, dimana semakin rendah jumlah sel-sel darah merah maka semakin rendah pula kandungan hemoglobin dalam darah. Kadar hematokrit ini dapat digunakan untuk mengetahui dampak infeksi dari $A$. hydrophila, sehingga dapat digunakan sebagai petunjuk kondisi kesehatan ikan setelah penginfeksian. Gambar 1 menunjukkan terjadi peningkatan setelah 3 hari dilakukan penginfeksian.

Dari Gambar 1 dapat diketahui bahwa kontrol tanpa pemberian serbuk daun majapahit dalam pakannya memiliki prosentase jumlah hematokrit yang lebih tinggi baik setelah perlakuan pemberian pakan selama 28 hari maupun setelah 3 hari ikan diinfeksi. Peningkatan prosentase hematokrit berkisar antara $24,09 \pm 0,03$ sampai $25,42 \pm 0,41$. Hal ini sesuai 


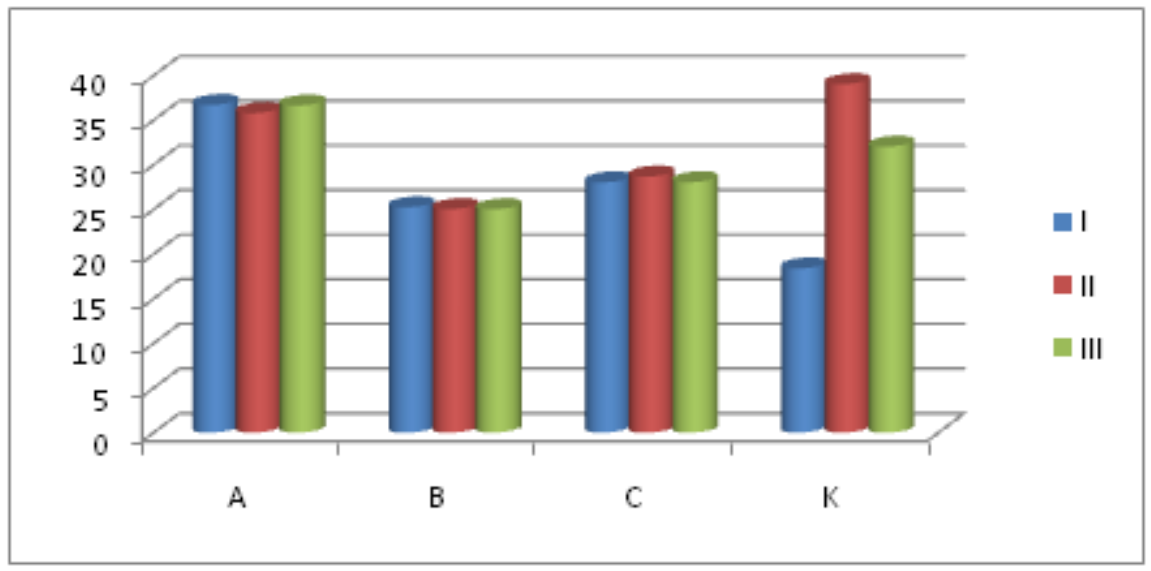

Gambar 1. Hasil pengukuran hematokrit pada ikan lele sangkuriang selama penelitian.

Keterangan : A,B,C adalah perlakuan $\mathrm{K}=$ kontrol , I,= pengambilan hematokrit hari ke 1 , II = pengambilan hari ke 28 dan $\mathrm{III}=$ pengambilan hari ke- 3 setelah infeksi

dengan penelitian yang dilakukan oleh Sa'diyah (2006) yang menyatakan bahwa kadar hematokrit ikan patin (Pangasius hypophthalmus) yang dipelihara dengan pemberian pakan mengandung larutan mahkota dewa (Phaleria macrocarpa) mengalami peningkatan setelah diinfeksi dengan $A$. hydrophila berkisar antara 24,14$26,18 \%$. Sementara hasil berbeda dengan penelitian yang dilakukan oleh Lukistyowati (2012), kadar hematokrit ikan patin setelah perendaman dengan berbagai dosis larutan sambiloto (Andrographis paniculata Ness) mengalami penurunan berkisar antara 10,70-24,30\% setelah diinfeksi dengan Edwardsiella tarda. Hasil penelitian (Chen et al., 2004) pada ikan nila menunjukkan bahwa hematokrit, dan glukosa dapat menjadi indikator untuk menunjukkan kondisi kesehatan ikan. Menurut Bond (1979) dalamSaragih et al, 2015) kadar hematokrit normal pada ikan teleostei berkisar antara 20-30\% dan pada ikan laut bernilai sekitar $42 \%$, ikan yang mengalami anemia mempunyai persentase hematokrit minimum $10 \%$.

Hematokrit adalah persentase eritrosit di dalam darah (Guyton 1997) dalam. Dopongtonung (2008). Hematokrit digunakan untuk mengukur perbandingan antara eritrosit dengan plasma, sehingga hematokrit memberikan rasio total eritrosit dengan total volume darah dalam tubuh. Nilai hematokrit adalah parameter yang berpengaruh terhadap pengukuran volume eritrosit, presentase nilai hematokrit ikan lele (Clarias spp) normal berkisar antara 30,8 - 45,5\% (Angka et al., 1985) dalam. Dopongtonung A. (2008). Nilai hematokrit secara langsung berhubungan dengan jumlah eritrosit dan konsentrasi hemoglobin. Maryani (2003) menyebutkan , nilai hematokrit yang lebih kecil dari $22 \%$ menunjukkan bahwa ikan mengalami anemia dan kemungkinan terinfeksi penyakit. Abdullah (2008) melaporkan bahwa nilai hematokrit akan mengalami penurunan pada ikan lele (Clarias spp) yang terinfeksi Aeromonas hydrophila. Menurut Irianto (2005), anemia pada ikan juga dapat disebabkan oleh defisiensi Fe dan vitamin E di dalam pakan.

\section{KESIMPULAN}

Hasil penelitianmenunjukkan bahwa berdasarkan analisa ANOVA perlakuan memberikan pengaruh yang sangat nyata pada penelitian dan dosis terbaik yang menunjukkan nilai hematokrit tertinggi adalah pada perlakuan A dengan dosis $7.5 \%$ dengan nilai peningkatan prosentase hematokrit berkisar antara $15,12 \pm 0,25$ sampai $25,42 \pm 0,41$.

\section{UCAPAN TERIMA KASIH}

Terima kasih penulis ucapkan kepada Universitas PGRI Ronggolawe Tuban yang telah mendanai penelitian ini melalui program Hibah DIPA UNIROW pendanaan tahun 2018 melalui Surat kontrak No. 07/SP2H/LEMLIT UNIROW/V/2018.

\section{DAFTAR PUSTAKA}

Abdullah, Y. (2008). Efektivitas Ekstrak Daun Paci Paci Leucas Lavandulaefolia Untuk Pencegahan dan Pengobatan Infeksi Penyakit Mas Motile Aeromonad Septicaemia Ditunjau Dari Patologi makro Dan Hematologi Ikan Lele Dumbo Clarias Sp. Skripsi Fakultas Perikanan Dan Ilmu Kelautan. IPB : Bogor.

Angka, S.L., Priosoeryanto, B.P., Lay, B.W., \& Harris, E. (2004). Penyakit Motile Aeromonad Septicaemia pada Ikan Lele Dumbo Clarias sp. Forum Pascasarjana. $27: 339-350$.

Bricknell, I., \& Dalmo, R.A. (2005). The use of immunostimulants in fish larval aquaculture. Fish \& Shellfish Immunology. 
Cheng, W., Liu, CH., Yeh, S.T., \& Chen, J.C. (2005). The immune stimulatory effect of sodium alginate on the white shrimp Litopenaeus vannamei and its resistance against Vibrio alginolyticus. Fish and Shellfish Immunology.

Chen, C.Y., Wooster, G.A., \& Bowser, P.R. (2004). Comparative blood chemistry and histopathology of tilapia infection with Vibrio vulnificus or Streptococcus iniae or exposed to carbon tetrachlorida, gentamicin, or cooper sulfate. Aquaculture 239: 421\%443.

Dopongtonung, A. (2008). Gambaran darah Ikan Lele (Clarias spp) Yang Berasal Dari Daerah Laladon Bogor. Skripsi. Fakultas Kedokteran Hewan Institut Pertanian Bogor.

Fujaya, Y. (2004). Fisiologi Ikan Dasar Pengembangan Teknologi Perikanan. Jakarta : Rineka Cipta. 179 hlm.

Irianto, A. (2005). Patologi Ikan Teleostei. Gadjah Mada University Press, Yogyakarta.

Jasmanindar, Y. (2009). Penggunaan Ekstrak Gracilaria verrucosa Untuk Meningkatkan Sistem Ketahanan Udang Litopenaeus vannamei. Tesis. IPB : Bogor

Luthfi M. (2017). Pengaruh Ekstrak Daun Majapahit (Crescentia cujete) Dengan Dosis yang Berbeda Untuk Mengurangi Aktivitas Bakteri Aeromonas hydrophila Pada Budidaya Ikan Nila (Oreochromis niloticus). Skripsi. Fakultas Perikanan dan Kelautan UNIROW.

Lukistyowati, I. (2012). Studi Efektivitas Sambiloto (Andrographis paniculata Ness.) untuk Mencegah Penyakit Edwardsiellosis pada Ikan Patin (Pangasius hypophthalmus). Laporan Hasil Penelitian Dana DIPA Universitas Riau. Lembaga Penelitian Universitas Riau. Pekanbaru. $15 \mathrm{hlm}$.

Maryani, M. (2003). Interaksi Antara Logam Berat Kadmium(Cd) dan Infeksi Bakteri Aeromonas Hydrophila Pada Ikan Mas Cyprinus Carpi. Skripsi Fakultas Perikanan Dan Ilmu Kelautan, IPB.

Purwanti, D. (2016). Analisa Pemberian Ekstrak Buah Majapahit (Crescentia cujete L.) Dengan Dosis Yang Berbeda Untuk Mengurangi Aktivitas Bakteri Aeromonas hydrophila Pada Benih Ikan Lele Sangkuriang (Clarias gariepinus). Skripsi. Tidak dipublikasikan. Program Studi Ilmu Perikanan, Fakultas Perikanan dan Ilmu Kelautan Universitas PGRI Ronggolawe Tuban.
Rahmaningsih, S., \& Andriani, R. (2016). Pengaruh Bahan Aktif Daun Majapahit (Crescentia cujete) Terhadap Respon Imun Udang Vannamei (Litopenaeus vannamei). Prosiding Seminar Nasional Pengembangan Sumber Daya Pedesaan dan Kearifan Lokal, Berkelanjutan VI Universitas Jendral Sudirman Purwokerto, ISBN:978-602-164315-0, Hal 156.

Rahmaningsih, S., \& Jumiati. (2016). Study Tentng Pemanfaatan Tanaman Majapahit (Crescentia cujete) Untuk Penanggulangan Bakteri Vibrio harveyi Secara In vitro, Prosiding Seminar Nasional Perikanan dan Kelautan VI,Fakultas Perikanan dan Ilmu Kelautan, Universitas Brawijaya Malang, Hal 52-58.

Rantam, F. A. (2003). Metode Imunologi. Airlangga University Press. Surabaya.

Ridlo, A., \& Pramesti, R. (2009). Aplikasi Ekstrak Rumput Laut Sebagai Agen Imunostimulan Sistem Pertahanan Non Spesifik Pada Udang (Litopenaeus vannamei). FPIK UNDIP. Ilmu Kelautan. Vol. 14.

Saragih S.P., Syawal H., \& Rauwaty M. (2015). Total Of Erythrocytes, Haematocrit, And Haemoglobin Changes Of Pangasius hypophthalmus That Were Immersed in Curcumin Extract And That Were in Infected by Aeromonas hydrophila. Skripsi. Fakultas Perikanan dan Ilmu Kelautan Universitas Riau.

Sa'diyah. (2006). Pemanfaatan Buah Mahkota Dewa (Phaleria macrocarpa) untuk Pencegahan Infeksi Penyakit MAS (Motile Aeromonad Septicaemia) ditinjau dari Gambaran Darah Ikan Patin (Pangasionodon hypophthalmus). Skripsi. Fakultas Perikanan dan Ilmu Kelautan Universitas Riau.

Subagiyo. (2009). Uji Pemanfaatan Rumput Laut Halimeda sp. Sebagai Sumber Makanan Fungsional Untuk Memodulasi Sistem pertahanan Non Spesifik Pada Udang Putih (Litopenaeus vannamei). Ilmu Kelautan. 